Zeitschrift für Kristallographie, Bd. 121, S. 349 - 368 (1965)

\title{
The crystal structure of dalyite
}

\author{
By S. G. FleET \\ Department of Mineralogy and Petrology, University of Cambridge, England \\ With 6 figures \\ (Received November 3, 1964)

\begin{abstract}
Auszug
Die Kristallstruktur von Dalyit, $\mathrm{K}_{1,70} \mathrm{Na}_{0,30} \mathrm{Zr}_{\mathrm{r}} \mathrm{Si}_{6} \mathrm{O}_{15}$, wurde bestimmt und mittels zweidimensionaler Fourier-Synthesen verfeinert. Es ist ein neuer Schichtsilikat-Typ mit Ringen aus vier, sechs und acht $\mathrm{SiO}_{4}$-Tetraedern. Die Schichten werden durch $\mathrm{ZrO}_{6}$-Oktaeder und $(\mathrm{K}, \mathrm{Na}) \mathrm{O}_{8}$-Polyeder zusammengehalten. Der Si-O-Abstand beträgt 1,54 bis $1,67 \AA$ ( $\pm 0,01 \AA$ ); das Mittel aus zwölf verschiedenen Abständen ist 1,62 $\AA$. Der mittlere $\mathrm{Zr}-\mathrm{O}$-Abstand ist $2,06 \pm 0,03 \AA$, der mittlere $\mathrm{K}(\mathrm{Na})-\mathrm{O}$-Abstand $3,02 \pm 0,13 \AA$.
\end{abstract}

\section{Abstract}

The crystal structure of dalyite, a potassium (sodium) zirconium silicate $\mathrm{K}_{1.70} \mathrm{Na}_{\mathbf{0 . 3 0}} \mathrm{ZrSi}_{\mathbf{6}} \mathrm{O}_{15}$, has been determined and refined by two-dimensional Fourier methods. It is a new type of sheet silicate containing four, six- and eight-membered rings of $\mathrm{SiO}_{4}$ tetrahedra. The sheets are joined by $\mathrm{ZrO}_{6}$ octahedra and by $(\mathrm{K}, \mathrm{Na}) \mathrm{O}_{8}$ polyhedra. The $\mathrm{Si}-\mathrm{O}$ distances range from $1.54 \AA$ to $1.67 \AA( \pm .01 \AA)$ and the average of twelve independent $\mathrm{Si}-\mathrm{O}$ distances is $1.62 \AA$. The average $\mathrm{Zr}-\mathrm{O}$ distance is $2.06 \AA( \pm .03 \AA)$, and the average $\mathrm{K}(\mathrm{Na})-\mathrm{O}$ distance $3.02 \AA( \pm .13 \AA)$.

\section{Introduction and summary of previous work}

Dalyite is a potassium (sodium) zirconium silicate first noticed in sections of rocks from Ascension Island by Professor C. E. Thlley, and first separated by Dr. S. O. AGRell. Its chemical composition, unit cell, $\mathrm{x}$-ray powder data and physical properties were published by VAN TASSEL (1952).

The mineral occurs in a medium-grained granite in the trachytic and basaltic tuffs of Green Mountain and Middleton Peak on Ascension Island. It is a rare accessory (about $0.2 \%$ ) in rocks which are mainly composed of microperthite and quartz, associated in varying propor- 
tions with aegirine, strongly pleochroic arfvedsonite and reddish-brown pleochroic aenigmatite. At the time of writing, this is the only locality where the occurrence of dalyite has been reported.

Table 1 lists the physical properties of dalyite and gives details of a microchemical analysis by Dr. M. H. Hey. The data have been summarized from VAN TASSEL's (1952) paper.

Table 1

Chemical composition and physical data of dalyite compiled from VAN TASSEL (1952)

a) Microchemical analysis by Dr. M. H. HEY

$\left.\begin{array}{lr|ll} & & \multicolumn{3}{|l}{\text { Metals on basis of } 15 \mathrm{O}} \\ \mathrm{SiO}_{2} & 61.85 & \mathrm{Si} & 5.95 \\ \mathrm{ZrO}_{2} & 21.70 & \mathrm{Zr} & 1.01 \\ \mathrm{~K}_{2} \mathrm{O} & 14.60 & \mathrm{~K} & 1.79 \\ \mathrm{Na}_{2} \mathrm{O} & 1.75 & \mathrm{Na} & 0.32\end{array}\right\} 2.11$

b) Physical data

Colourless, transparent. Lustre, vitreous.

Optical constants: $\alpha=1.575 ; \quad \beta=1.590 ; \quad \gamma=1.601 ; 2 V_{\alpha}=72^{\circ}$

$$
\alpha: c=7^{\circ} \text {; axial plane to }(100)=18^{\circ} \text {. }
$$

Density 2.84. Hardness $71 / 2$. Cleavages (101) and (010).

Twinning not infrequent with (100) as compositon plane.

c) Unit cell

Triclinic

$$
\begin{array}{l|l|l}
a=7.51 \pm .07 \AA & b=7.73 \pm .08 \AA & c=7.00 \pm .07 \AA \\
\alpha=106^{\circ} \pm 1^{\circ} & \beta=113.5^{\circ} \pm 1^{\circ} & \gamma=99.5^{\circ} \pm 1^{\circ}
\end{array}
$$

Unit-cell content $(\mathrm{K} / \mathrm{Na})_{2} \mathrm{ZrSi}_{6} \mathrm{O}_{15}$.

The chemical analysis shows that the empirical formula is probably $\mathrm{K}_{2} \mathrm{ZrSi}_{6} \mathrm{O}_{15}$ where sodium replaces part of the potassium. There is a possibility that a small amount of $\mathrm{Hf}$ replaces $\mathrm{Zr}$ (VAN $\mathrm{T}_{A S S E L}, 1952$ ), but this has been neglected in the structure analysis.

The purpose of the structure determination was to discover the nature of the $\mathrm{Si}_{6} \mathrm{O}_{15}$ network and to find the relationship between dalyite and wadeite $\left(\mathrm{K}_{2} \mathrm{ZrSi}_{3} \mathrm{O}_{9}\right)$ to which dalyite is chemically most 
closely related. A complete determination of the structure proved possible with two-dimensional $\mathrm{x}$-ray diffraction data, and it was considered that highly accurate bond lengths, anisotropic temperature factors etc. were of too marginal an interest to warrant a full threedimensional analysis.

\section{Materials used}

Grains from rocks preserved in Cambridge (Harker slide no.57219) were selected for the $\mathrm{X}$-ray work. HEY's analysis (VAN TASSEL, 1952) was taken as the basis for the structure determination, the chemical composition being idealized as $\mathrm{K}_{1.70} \mathrm{Na}_{0.30} \mathrm{ZrSi}_{6} \mathrm{O}_{15}$. A regularly-shaped, untwinned crystal about $0.15 \mathrm{~mm}$ in all dimensions was chosen to give the best compromise between the conflicting demands for small absorption, small secondary extinction and strong reflection intensity.

\section{Cell dimensions and space group}

Dalyite is triclinic. Its cell dimensions were redetermined in the present work since VAN TASSEL's (1952) values were only accurate to $1 \%$ (cf. Table 1) and would have been one of the greatest sources of error in the interatomic distances.

Precession photographs were used to determine cell angles; axial lengths were found subsequently from oscillation pictures by the method described by Weisz, Cochran and Cole (1948) using extrapolation against $\sin ^{2} \theta$ (FARQUHAR and Lipson, 1946).

Final values were $\quad a=7.371 \pm .003 \AA^{1}$

$b=7.730 \pm .003 \AA$

$c=6.912 \pm .002 \AA$

$\alpha=106^{\circ} 14^{\prime} \pm 2^{\prime 2}$

$\beta=111^{\circ} 27^{\prime} \pm 2^{\prime}$

$\gamma=100^{\circ} 0^{\prime} \pm 2^{\prime}$.

To decide on the presence or absence of a centre of symmetry, reflections with $\frac{\sin \theta}{\lambda}<0.7$ in $h k 0,0 k l, h 0 l$ zones were subjected to the statistical tests of Howells, Phillips and Rogers (1950). Figure 1 gives the experimental curves. Although the curves follow the centrosymmetric curve at small values of $z$, they move over towards the

\footnotetext{
1 Errors are limits estimated from experimental graphs of $a^{*}, b^{*}, c^{*}$ against $\sin ^{2} \theta$.

${ }^{2}$ Errors calculated from the reproducibility of several measurements.
} 
non-centrosymmetric one at higher values. It is not, therefore, possible to make a direct deduction about the presence of a centre.

Reflections in each zone were next subjected to the statistical test suggested by Ramachandran and Srintvasan (1959). Again using reflections with $\frac{\sin \theta}{\lambda}<0.7$, the values of their test ratio $N_{2} / N_{1}$ were $0.67(h k 0), 0.62(0 k l), 0.59(h 0 l)$ as compared with the theoretical

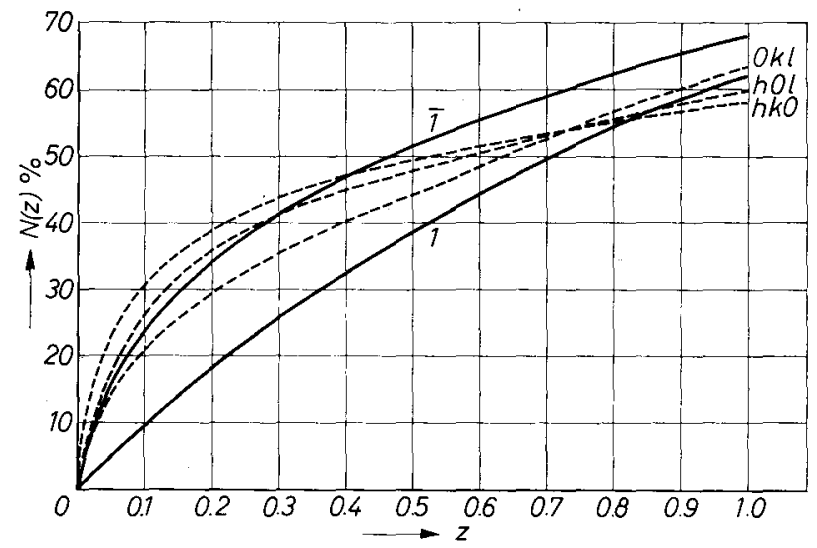

Fig. 1. $N(Z)$ test for $h k 0, h 0 l$ and $0 k l$ reflections. Experimental curves are dotted, theortical curves continuous

values of 0.776 for a centrosymmetric structure and 1.96 for a noncentrosymmetric one. Here then is clear indication of the existence of a centre. As a further check, tests for piezo- and pyro-electricity were carried out, but with negative results.

The structure was therefore assumed to be centrosymmetric at the start of the refinement. Further work confirmed that any departures from centrosymmetry would be small, and that the space group is therefore probably $P \overline{\mathbf{1}}$.

\section{Collection of intensities}

$\mathrm{X}$-ray reflections $h k 0, h 0 l$, and $0 k l$ were recorded on Weissenberg photographs with filtered MoK$\alpha$ radiation using the multiple-film technique (RoBertson, 1943). Intensities recorded on the film were measured visually by comparison with an intensity scale made using the well-shaped $(1 \overline{2} 0)$ reflection from the crystal. Where $\alpha_{1}, \alpha_{2}$ doublets were completely resolved, their sum was accepted as peak intensity. Intensity data were collected in all three projections to values of $\frac{\sin \theta}{\lambda}=1.36 \AA^{-1}$. The intensity data for each projection, read from 
various films, were placed on the same relative scale by comparing the intensities of zones of reflections recorded on more than one film.

Very many high-angle reflections were unobserved despite 200 -hour exposures. In fact, there were 94 non-zero $h k 0$ reflections, $90 h 0 l$ and $1180 \mathrm{kl}$. The range of scaled intensities extended from approximately 1 to 200 .

\section{Corrections and errors}

The intensities were corrected for Lorentz and polarisation effects, and for absorption with programs written for Edsac II by S. DarLow and M. WeLLS. There was a small amount of dispersion caused by $\mathrm{Zr}$ with MoK$\alpha$ radiation and this was allowed for by an adjustment of scattering factor (cf. Section 7). No correction was made for the measuring error introduced in the intensities by the increasing resolution of the $\alpha_{1}, \alpha_{2}$ doublet with $\sin \theta$. Partial allowance was made for secondary extinction by omitting some intense low-angle reflections from the $F_{0}-F_{\mathrm{c}}$ syntheses during refinement; the reflections so treated are marked with an asterisk in Table 2 where values of $F_{\mathrm{o}}$ 's and final $F_{\mathrm{c}}$ 's are listed.

\section{Deduction of trial structure}

Dalyite has one formula unit $(\mathrm{K}, \mathrm{Na})_{2} \mathrm{ZrSi}_{6} \mathrm{O}_{15}$ per cell, and it was therefore at once possible to deduce that $\mathrm{Zr}$ atoms must lie on centres of symmetry at the cell origin. The heavy-atom method suggested itself as the most promising way of determining the positions of the other atoms. Patterson syntheses were calculated for the projections onto each of the planes (100), (010) and (001). Besides the origin peak, there were eight other large peaks on each map: it was assumed that these peaks were at the ends of vectors between the $\mathrm{Zr}$ and the two $\mathrm{K} / \mathrm{Na}$ and six $\mathrm{Si}$ atoms. Since the $\mathrm{Zr}$ was at the cell origin, the coordinates of the other cations could at once be written down. They were:

Fractional coordinates

\begin{tabular}{c|c|c|c}
\hline Site & $x$ & $y$ & $z$ \\
\hline 1 & .2850 & .1950 & .7000 \\
2 & .5000 & .6800 & .6800 \\
3 & .1800 & .7400 & .3100 \\
4 & .1600 & .6150 & .8450
\end{tabular}

and the centrosymmetrically-related sites. 
Table 2. Observed and calculated structure factors

The calculated values are for two formula weights of $(\mathrm{K}, \mathrm{Na})_{2} \mathrm{ZrSi}_{6} \mathrm{O}_{15}$

\begin{tabular}{|c|c|c|c|c|c|c|c|c|}
\hline h $k 1$ & $F_{0}$ & $F_{c}$ & b $3<1$ & $F_{0}$ & $F_{c}$ & \& $\leqslant 1$ & $F_{0}$ & $F_{c}$ \\
\hline 100 & 57 & 69 & 050 & 88 & 96 & 102 & 20 & $2 I_{t}$ \\
\hline 300 & 24 & 23 & 150 & 69 & 63 & 002 & 86 & -101 \\
\hline 400 & 73 & 73 & 350 & 76 & 78 & 202 & $117^{*}$ & 142 \\
\hline $\begin{array}{l}600 \\
0\end{array}$ & 90 & 87 & 550 & 39 & 37 & 302 & 94 & 91 \\
\hline 700 & 27 & 24 & 750 & 53 & 56 & 402 & 25 & -17 \\
\hline 1000 & 54 & 43 & $\overline{8} 60$ & 49 & 48 & 702 & 58 & 56 \\
\hline $\begin{array}{l}8 \\
10\end{array}$ & 24 & 19 & $\overline{7} 60$ & 33 & 26 & $\overline{10} 03$ & 64 & 56 \\
\hline 710 & 22 & 22 & 460 & 89 & 100 & $\overline{9} 03$ & 37 & 35 \\
\hline 610 & 62 & -66 & $\overline{2} 60$ & 32 & 32 & $\overline{8} 03$ & 34 & 30 \\
\hline$\overline{5} 10$ & 56 & 47 & $\overline{1} 60$ & 30 & -25 & 603 & 42 & 43 \\
\hline$\overline{4} 10$ & 93 & 92 & 060 & 48 & 41 & $\overline{5} 03$ & 52 & 49 \\
\hline$\overline{3} 10$ & 14 & 12 & 260 & 58 & 64 & $\overline{4} 03$ & 129 & 160 \\
\hline$\overline{2} 110$ & 66 & -51 & 360 & 61 & 51 & $\overline{3} 03$ & 19 & -13 \\
\hline 110 & 135 & 138 & 460 & 34 & 37 & $\overline{2} 03$ & 25 & 18 \\
\hline $\begin{array}{lll}2 & 1 & 0\end{array}$ & $102 *$ & 110 & 560 & 26 & -27 & $\begin{array}{lll}1 & 0 & 3\end{array}$ & 72 & 74 \\
\hline 310 & $127^{*}$ & 143 & $\overline{7} 70$ & 46 & 45 & $\begin{array}{lll}0 & 0 & 3\end{array}$ & 59 & 65 \\
\hline $4: 0$ & 52 & -50 & 570 & it: & 39 & 203 & 94 & 95 \\
\hline 610 & 40 & 30 & 570 & 35 & 29 & 303 & 62 & 60 \\
\hline 710 & 49 & 49 & $\overline{4} 70$ & 26 & 25 & 403 & 49 & 42 \\
\hline$\overline{9} 20$ & 69 & 68 & $\overline{2} 70$ & 69 & 76 & 603 & 77 & 61 \\
\hline$\overline{8} 20$ & 72 & 73 & $\overline{1} 70$ & 85 & 89 & 904 & 37 & 34 \\
\hline$\overline{7} 20$ & 71 & 70 & 270 & 24 & 26 & $\overline{8} 04$ & 26 & 38 \\
\hline$\overline{5} 20$ & 50 & 41 & 370 & 50 & 44 & $\overline{7} 04$ & 31 & 27 \\
\hline$\overline{4} 20$ & 22 & 15 & 470 & 32 & 40 & 604 & 74 & 80 \\
\hline$\overline{2} 20$ & 101 & 106 & 570 & 44 & 55 & $\overline{1} 04$ & 22 & -25 \\
\hline$\overline{1} 20$ & $196 *$ & 207 & $\overline{6} 80$ & 35 & 35 & $\overline{3} 04$ & $9 h$ & 112 \\
\hline 020 & 74 & -66 & 580 & 93 & 92 & 204 & 109 & 131 \\
\hline 220 & $117 *$ & 122 & $\begin{array}{l}1 \\
80\end{array}$ & 52 & 16 & 104 & 78 & 80 \\
\hline 320 & 110 & 120 & $1 B 0$ & 65 & 63 & 004 & 43 & 46 \\
\hline 420 & 31 & 27 & 580 & 37 & 39 & 304 & 34 & 31 \\
\hline$=20$ & 58 & 60 & $\overline{4} 90$ & 62 & 66 & 104 & 66 & 57 \\
\hline $6 \simeq 0$ & 27 & 26 & $\overline{3} 90$ & 75 & 75 & 504 & 40 & 36 \\
\hline$\overline{6} 30$ & 99 & 111 & $\overline{2} 90$ & 43 & 40 & $\overline{9} \cap 5$ & 49 & 53 \\
\hline$\overline{5} ; 0$ & 71 & 64 & 190 & 42 & 36 & $\overline{8} 05$ & 27 & 19 \\
\hline$\overline{3} 30$ & 41 & -35 & 290 & 55 & 50 & $\overline{7} 05$ & 41 & 36 \\
\hline$\overline{2} 30$ & 87 & $9 n$ & $\overline{3} 100$ & 38 & 39 & 505 & 45 & 42 \\
\hline 030 & 42 & 36 & $\overline{2} 100$ & 57 & 59 & $\overline{4} 05$ & 57 & -52 \\
\hline 130 & 80 & 87 & $\because 100$ & ito 0 & 41 & $\overline{3} 05$ & 77 & 83 \\
\hline 230 & 67 & 55 & 0110 & 32 & 30 & 203 & 85 & 108 \\
\hline 330 & 40 & -36 & 701 & 47 & 41 & 105 & 57 & 51 \\
\hline $43 n$ & 77 & 79 & $\begin{array}{lll}6 & 0 & 1\end{array}$ & 45 & 40 & 005 & 52 & -50 \\
\hline $53 n$ & 40 & 40 & $\overline{5} 01$ & 62 & 61 & 105 & 50 & 51 \\
\hline 630 & 37 & 41 & $\overline{3} 01$ & 45 & 42 & 305 & 44 & 38 \\
\hline 640 & 71 & 73 & $\begin{array}{lll}\overline{2} & 0 & 1\end{array}$ & 50 & 62 & 505 & 56 & 43 \\
\hline$\overline{5} 40$ & 32 & 27 & $\overline{1} 0:$ & $7^{\prime 4}$ & 88 & $\overline{8} 06$ & 10 & 33 \\
\hline$\overline{4} 40$ & 41 & 38 & $\begin{array}{llll}0 & 0 & 1\end{array}$ & 52 & 48 & $\overline{6} 06$ & 64 & 64 \\
\hline$\overline{3} 40$ & 93 & to2 & 101 & $137^{*}$ & 149 & $\overline{5} 06$ & 19 & 27 \\
\hline$\overline{2} 40$ & 54 & 47 & $\because 01$ & 52 & -48 & $\pi 06$ & 53 & 52 \\
\hline 0 & 22 & 20 & 301 & 71 & 63 & $\overline{3} 06$ & 33 & -25 \\
\hline 140 & 83 & 73 & $40 \mathrm{t}$ & 63 & 59 & $\overline{2} 06$ & 19 & 21 \\
\hline 240 & 48 & 37 & 701 & 45 & 47 & 106 & 27 & 23 \\
\hline 440 & 57 & 55 & $\overline{9} 02$ & ${ }_{4} 5$ & 49 & 000 & 81 & 77 \\
\hline 540 & 46 & 43 & $\overline{8} 0=$ & 38 & 37 & 106 & 30 & 38 \\
\hline$\overline{7} 50$ & 56 & 57 & $\overline{6} 02$ & 40 & -39 & 206 & 63 & 52 \\
\hline$\overline{5} 50$ & 57 & 52 & 502 & 108 & 126 & 606 & 63 & 54 \\
\hline$\overline{3} 50$ & 106 & 114 & $\overline{4} 02$ & 82 & 89 & $\overline{10} 07$ & 46 & 42 \\
\hline$\overline{1} 50$ & 59 & 58 & $\begin{array}{lll}\overline{2} & 0 & 2\end{array}$ & 34 & -19 & $\overline{7} 07$ & 88 & 75 \\
\hline
\end{tabular}

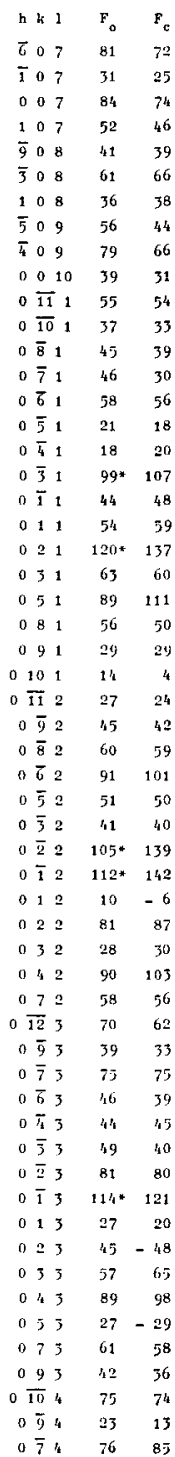

th $k 1$ F $\quad F_{0}$ $0 \overline{6} 4 \quad 46-28$ $0 \overline{4} 4 \quad 112 \quad 138$ $0 \overline{2} 4 \quad 46 \quad 43$ $0 \overline{1} 4 \quad 26-24$ $\begin{array}{llrr}0 & 14 & 109 & 133\end{array}$ $024 \quad 59 \quad 56$ $\begin{array}{lllll}0 & 5 & 4 & 39 & 32\end{array}$ $\begin{array}{llll}0 & 64 & 52 & 51\end{array}$ $0 \longdiv { 1 0 } 5 \quad 3 6 \quad 3 4$

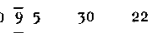
$\begin{array}{lll}\overline{8} & 58 & 55\end{array}$

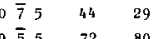

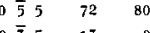
$0 \overline{3} 5 \quad 13 \quad 9$

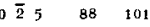

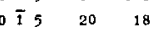
$1562 \quad 62$ $025 \quad 54 \quad 58$ $035 \quad 46 \quad 38$ $0 \begin{array}{llll}4 & 5 & 23 & 16\end{array}$

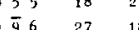
$\overline{8} 6$
0 $51 \quad 50$ $0 \begin{aligned} & 66 \\ & 0565\end{aligned}$ $056 \quad 59 \quad 5$ $0 \overline{4} 6 \quad 20 \quad 15$

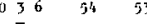
$\begin{array}{llll}0 & 2 \\ 0 & 20 & 20\end{array}$ $\begin{array}{llll}0 & \overline{1} 6 & 28 & 24\end{array}$ $\begin{array}{llll}016 & 15 & -14\end{array}$ II $7 \quad 51 \quad 47$ $\overline{10} 7 \quad 33 \quad 29$ $0 \overline{7} 7 \quad 39 \quad 42$ ह 7 35 3 $0 \overline{4} 7 \quad 46 \quad 42$ $0 \overline{3} 7 \quad 5 \overline{5} \quad 50$ $0 \sqrt{2} 7 \quad 22-17$ 0 $\overline{1} 7 \quad 42 \quad 40$ $\begin{array}{llll}0 & 57 & 67 & 52\end{array}$ $0 \begin{array}{lll}0 & 8 & 53\end{array}$ $\begin{array}{llll}0 & 8 & 43\end{array}$ $\begin{array}{llll}0 & 6 & 8 & 41\end{array}$

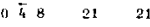
$0 \overline{3} 8 \quad 30 \quad 26$ $\begin{array}{llll}0 & \overline{2} 8 & 37 & 34\end{array}$ $\begin{array}{lllll}0 & 1 & 8 & 45 & 31\end{array}$ a $28 \quad 74 \quad 66$

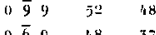
$\begin{array}{llll}0 & 6 & 9 & 48\end{array}$ (1) 59 3h 2 $0 \overline{3} 918 \quad 2$ (4) 199 $0 \overline{7} 10 \quad 46 \quad 4$

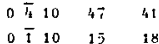

* reflections onitted during refinenert [see text].

It was not possible to determine at this stage which of the cation positions were $\mathrm{K} / \mathrm{Na}$ and which $\mathrm{Si}$ because there was little difference between the four crystallographically-distinct Patterson peaks. 
Presumably the $\mathrm{K} / \mathrm{Na}$ atoms had large thermal motion and hence peak heights that were very little different from those of the silicon atoms.

To discover the $\mathrm{K} / \mathrm{Na}$ positions, the interbond distances between all the cations were calculated. The cations in site 1 and its centrosymmetrically-realted site are farthest from the other cations (nearest cation neighbour $3.51 \AA$ away): cations in the other sites have neighbours nearer to hand $(3.0,3.0,3.05 \AA$ away). Clearly the $\mathrm{K} / \mathrm{Na}$ atoms must lie in site 1, and $\mathrm{Si}$ atoms in sites 2,3 and 4 .

In order to determine the oxygen positions, Fourier syntheses were obtained with the signs calculated from the known cation coordinates. It was easy to pick out oxygen peaks from the resulting maps. There were 15 oxygens per cell. All were in two-fold general positions except one which lay at the centre of symmetry at $\frac{1}{2} \frac{1}{2} \frac{1}{2}$. Inspection of cation and anion positions showed that the most reasonable structure was one consisting of sheets of $\mathrm{SiO}_{4}$ tetrahedra approximately parallel to (010), linked by $\mathrm{ZrO}_{6}$ octahedra and large $\mathrm{K} / \mathrm{Na}$ coordination polyhedra.

The sheets are very irregular, but can be described as made up of linked rings containing four, six and eight $\mathrm{SiO}_{4}$ tetrahedra; alternate tetrahedra pointing roughly up or down. The trial structure proved essentially correct on refinement and will be discussed in detail later (Section 8).

\section{Refinement}

Refinement was carried out by difference-Fourier syntheses calculated with $h k 0, h 0 l$ and $0 k l$ reflections. Each projection was refined independently to the limit omitting some reflections (those asterisked in Table 2) because they appeared to be suffering from extinction. When average temperature factors had been once worked out, $F_{\mathrm{o}}$ 's were scaled to $F_{\mathrm{c}}$ 's using one scale factor.

Scattering factors were calculated assuming that all atoms are half-ionized and that $\mathrm{K} / \mathrm{Na}$ cations are composite ones of composition $85 \% \mathrm{~K}, 15 \% \mathrm{Na}$. Scattering-factor curves were constructed by interpolation from those in the literature quoted by ForsYTH and WeLLS (1959), and an expression of the form $f(x)=A \exp \left(-a x^{2}\right)+$ $B \exp \left(--b x^{2}\right)+C$ was fitted to them by the least-squares process they suggested. The constants so found are given in Table 3 . The constant $C$ in the expression for the $\mathrm{Zr}$ scattering factor was reduced by 2.8 to 
Table 3. Scattering factor constants calculated for half-ionized atoms (After Fonsyth and WeLLS, 1959)

\begin{tabular}{l|r|r|r|r|c}
\hline Half-ionized atom. & \multicolumn{1}{|c|}{$A$} & $a$ & \multicolumn{1}{c|}{$B$} & $b$ & $C$ \\
\hline $\mathrm{O}^{-}$ & 4.322 & 6.983 & 3.243 & 36.48 & 1.434 \\
$\mathrm{Si}^{2+}$ & 7.616 & 2.857 & 2.252 & 63.64 & 2.132 \\
$\mathrm{Zr}^{2+}$ & 17.835 & 1.788 & 12.775 & 19.73 & 4.590 \\
$\mathrm{~K} / \mathrm{Na}^{1 / 2+}$ & 7.350 & 0.952 & 7.603 & $\mathbf{1 6 . 5 2}$ & 1.749
\end{tabular}

Table 4

a) Atomic coordinates of dalyite

\begin{tabular}{|c|c|c|c|c|}
\hline & & \multicolumn{3}{|c|}{ Fractional coordinates } \\
\hline & & $x$ & $y$ & $z$ \\
\hline \multirow[t]{2}{*}{ Atoms in special positions: } & $\mathrm{Zr}$ & 0 & 0 & 0 \\
\hline & $\mathrm{O}_{1}$ & $1 / 2$ & $1 / 2$ & $1 / 2$ \\
\hline \multirow[t]{11}{*}{ Atoms in two-fold general positions: } & $\mathrm{K} / \mathrm{Na}$ & .2932 & .1887 & .7083 \\
\hline & $S i_{1}$ & .4975 & .6817 & .6852 \\
\hline & $\mathrm{Si}_{2}$ & .1644 & .6226 & .8446 \\
\hline & $\mathrm{Si}_{3}$ & .1850 & .7389 & .3092 \\
\hline & $\mathrm{O}_{2}$ & .0120 & .5768 & .3029 \\
\hline & $\mathrm{O}_{3}$ & .0814 & .8043 & .8127 \\
\hline & $\mathrm{O}_{4}$ & .1024 & .9131 & .2679 \\
\hline & $\mathrm{O}_{5}$ & .2511 & .6444 & .1058 \\
\hline & $\mathrm{O}_{6}$ & .2810 & .2075 & .1254 \\
\hline & $\mathrm{O}_{7}$ & .3565 & .6017 & .7787 \\
\hline & $\mathrm{O}_{8}$ & .3904 & .8069 & .5495 \\
\hline
\end{tabular}

b) Standard deviations of coordinates

$$
\begin{array}{ll}
\mathrm{K} / \mathrm{Na} & \sigma\left(x_{n}\right)=0.008 \AA \\
\mathrm{Si}_{1-3} & \sigma\left(x_{n}\right)=0.004 \AA \\
\mathrm{O}_{2-8} & \sigma\left(x_{n}\right)=0.012 \AA
\end{array}
$$

c) Temperature factors [used in the expression $\left.\exp \left(-B \sin ^{2} \theta / \lambda^{2}\right)\right]$

\begin{tabular}{l|c|c|c|c|c|c|c}
\multicolumn{2}{c}{ Isotropic } \\
\hline \multirow{2}{*}{ Atoms } & $B$ & Atoms & $r$ & $B_{r}\left(\hat{\AA}^{2}\right)$ & $\widehat{r x}$ & $\widehat{r y} y^{*}$ & $\begin{array}{c}\hat{r} \text { normal } \\
\text { to } x \text { and } y^{*}\end{array}$ \\
\hline $\mathrm{Zr}$ & $0.40 \AA^{2}$ & $\mathrm{~K} / \mathrm{Na}$ & $X$ & 3.8 & $65^{\circ}$ & $75^{\circ}$ & $151^{\circ}$ \\
$\mathrm{Si}_{1-3}$ & 0.22 & & $Y$ & 0.8 & & & \\
$\mathrm{O}_{2-8}$ & 0.80 & & $Z$ & 1.2 & & & \\
& & \multirow{2}{*}{$\mathrm{O}_{1}$} & $X$ & 1.8 & $46^{\circ}$ & $55^{\circ}$ & $116^{\circ}$ \\
& & & $Y$ & 0.7 & & &
\end{tabular}



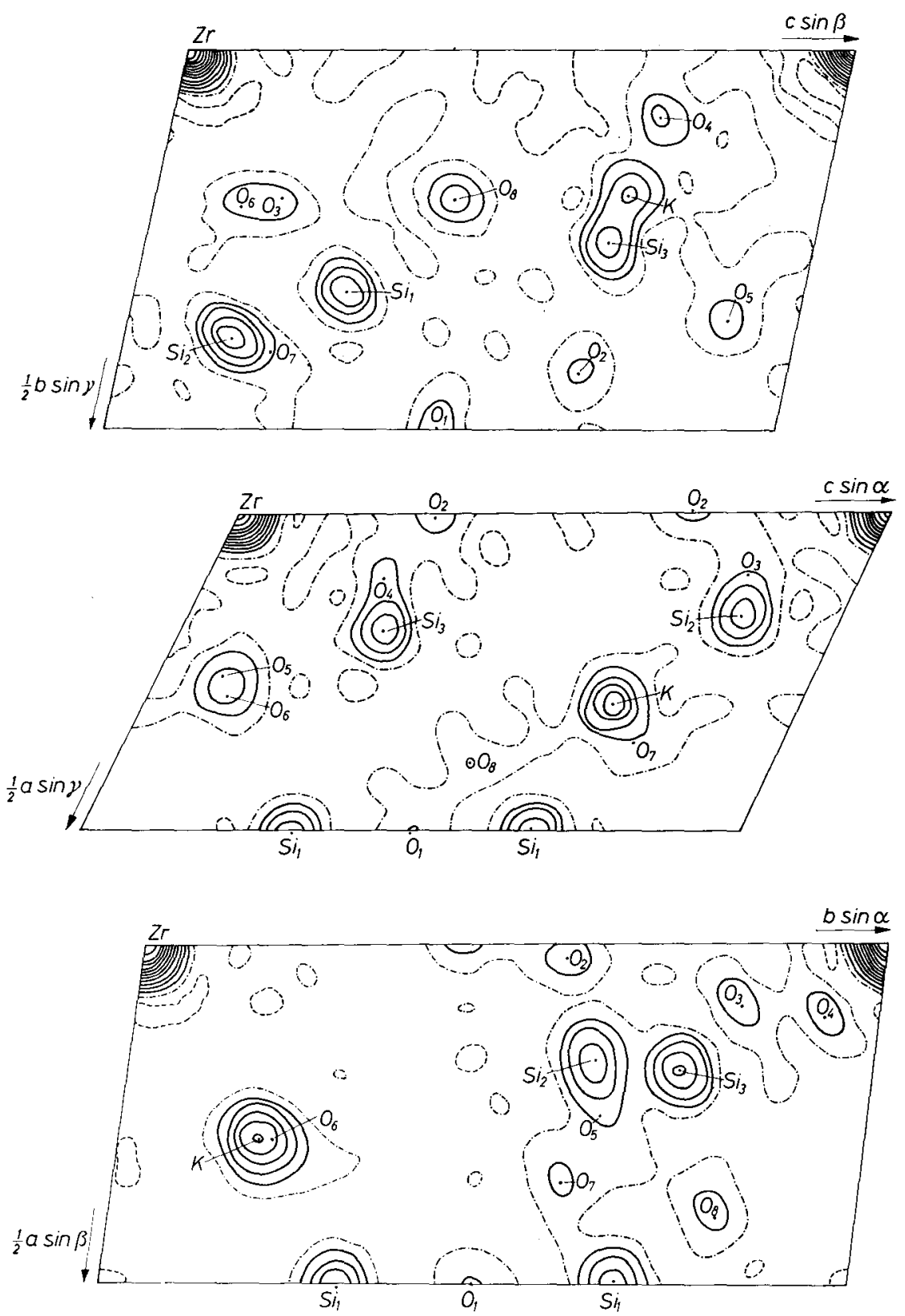

Fig. 2. $x, y$ and $z$ axis electron-density projections of dalyite. Half the unit cell is shown in each case. Contours are at arbitrary equal intervals; zero contours are chained and negative ones dashed. Atomic positions are marked 
take account of dispersion (cf. Dauben and Templeton, 1955). The small imaginary component of the dispersion correction for $\mathrm{Zr}(0.8)$ was neglected, as were dispersion corrections for all other atoms.

Isotropic temperature factors were chosen for the different classes of atom to minimize the average peak heights at atomic sites on the difference maps. Several atoms showed evidence of anisotropy, but anisotropic temperature factors were only applied to the most anisotropic, which were the $\mathrm{K} / \mathrm{Na}$ atom and $\mathrm{O}_{1}$.

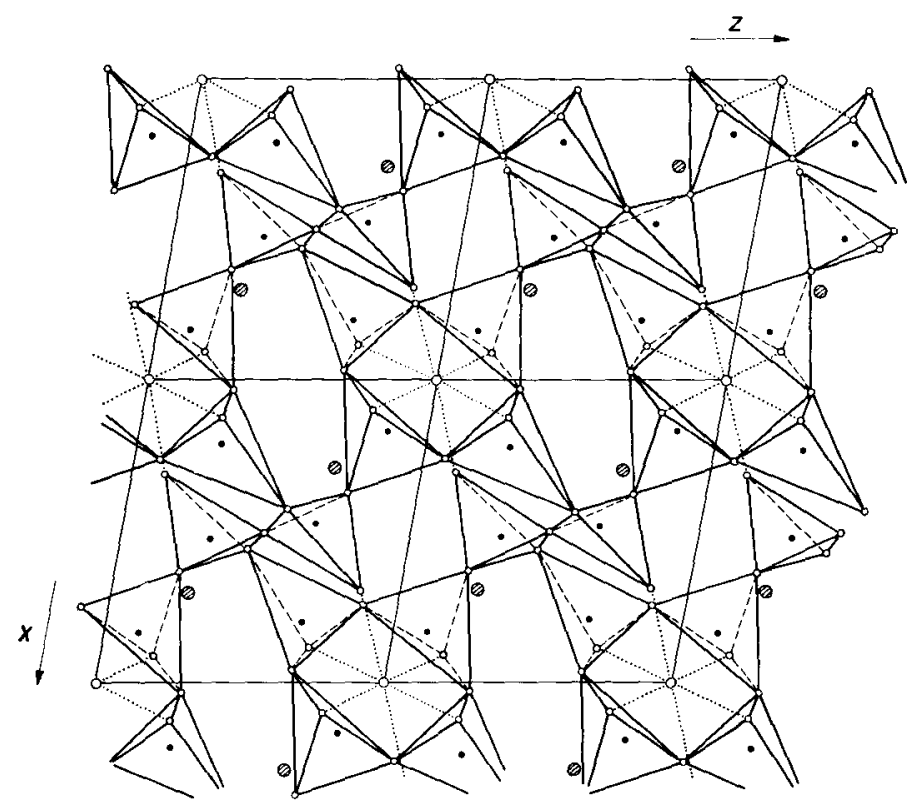

Fig. 3(i). ( $\left(\mathrm{Si}_{2} \mathrm{O}_{5}\right)_{n}$ framework of dalyite viewed along $y$ axis. ( $\mathrm{ZrO}$ bonds dotted)

Theinitial "discrepancy factors", $R$, were $31.3 \%, 35.0 \%$ and $36.0 \%$ for $h k 0, h 0 l$ and $0 k l$ reflections respectively. At the limit of refinement, the values had fallen to $8.1 \%, 11.9 \%$ and $12.2 \%$, and the final overall $R$ factor was $10.8 \%$.

The final atomic coordinates with their standard deviations are given in Table 4 . The standard deviations have been calculated from the final $F_{0}-F_{\mathrm{c}}$ syntheses with the formula

$$
\sigma\left(x_{n}\right)=\left\{\overline{\left[\frac{\partial\left(\varrho_{o}-\varrho_{c}\right)}{\partial x}\right]^{2}}\right\}^{1 / 2} / C_{n}
$$


(Cochran, 1951); it has been assumed that $\sigma\left(x_{n}\right)$ is the same in every direction, and $C_{n}$ (the curvature at the atomic peak) is estimated from the postulated scattering factor curves modified by temperature factors.

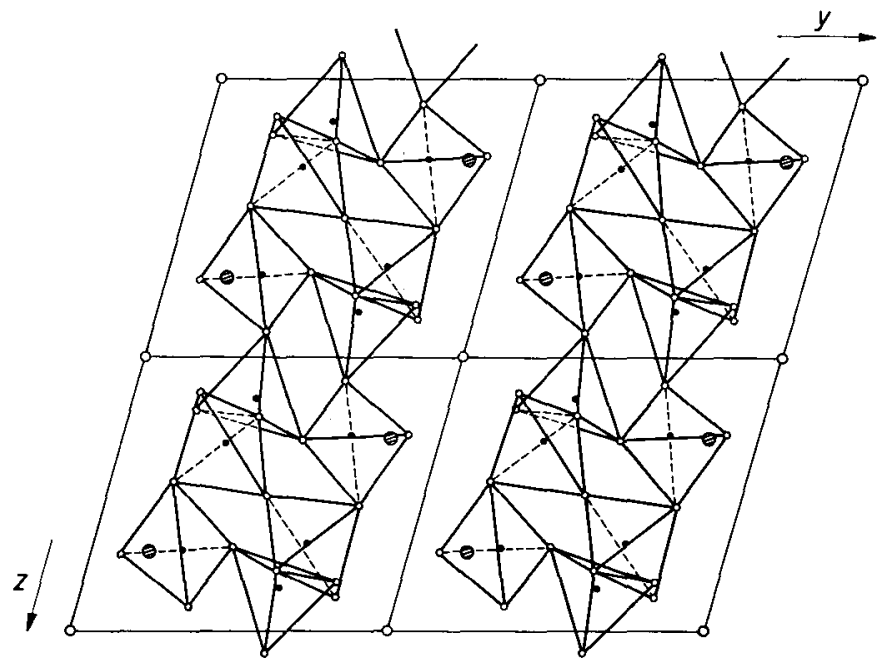

(ii)

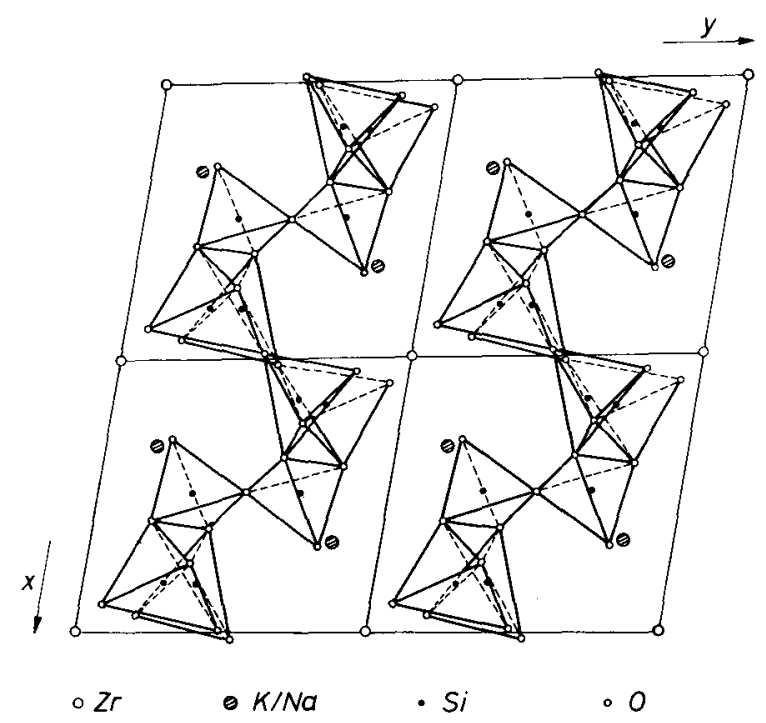

(iii)

Figs. 3(ii) and (iii). $\left(\mathrm{Si}_{2} \mathrm{O}_{5}\right)_{n}$ framework viewed along $x$ and $z$ axes 
The final isotropic temperature factors for each class of atom also appear in Table 4, together with details of the anisotropic temperature factors of atoms $\mathrm{K} / \mathrm{Na}$ and $\mathrm{O}_{1}$.

\section{Discussion of the structure}

Figure 2 shows electron density maps of dalyite calculated with final coordinates and the complete list of $F_{0}$ 's. Figure 3 shows the nature of the $\mathrm{SiO}_{4}$ tetrahedral linkage. The tetrahedra form corrugated sheets, approximately parallel to $(010)$, which may be considered to be formed by linking distorted $\beta$-wollastonite chains (cf. Fig.4). Successive wollastonite chains have different $y$ coordinates; one chain has $\mathrm{Si}$ atoms at $y=0.62,0.68$ and 0.74 , and the next at $y=0.38$, 0.32 and 0.26 , so that looked at end on [cf. Figs. 3(ii) and 3(iii)], the sheets are two tetrahedra thick.

The $\mathrm{Si}-\mathrm{O}$ sheets are linked by regular $\mathrm{ZrO}_{6}$ octahedra and by irregular $(\mathrm{K} / \mathrm{Na}) \mathrm{O}_{8}$ polyhedra. $\mathrm{Zr}-\mathrm{O}$ bonds are outlined in Fig. 3(i).

The sheets are of a kind not previously found in silicates. They contain 4-, 6- and 8- membered rings of $\mathrm{SiO}_{4}$ tetrahedra. Previously known sheet silicates are made up either entirely of 6 -membered rings of tetrahedra, or of linked 4- and 8-membered rings ${ }^{3}$. Structures based on sheets of 6 -membered rings may have all free tetrahedral vertices pointing the same way as in micas, talc etc., or have more distorted rings linked to give corrugated sheets as in $\mathrm{Li}_{2} \mathrm{Si}_{2} \mathrm{O}_{5}$ (LIEBAU, 1961a), petalite (Liebau, 1961c) or sambornite (Dovglass, 1958). Structures based on 4- and 8-membered rings (e.g. apophyllite, TAYLOR and Náray-Szabó, 1931; gillespite, Pabst, 1943) are formed by linking rings of 4 tetrahedra so that successive rings have their free vertices pointing in opposite directions. Figure 5 shows idealized drawings of the three ${ }^{3}$ types of layer silicate now known and includes more detailed diagrams of the $\mathrm{Si}-\mathrm{O}$ network in some well known examples.

LIEBAU (1962) has classified sheet silicates on the basis of the type of silicate chain from which the sheets can be constituted. $\mathrm{He}$ lists the structures as Einer-, Zweier-, Dreier-, Vierereinfachschichten etc. according to the number of tetrahedra in the repeat unit of the

${ }^{3}$ MAMedov and BeLov (1958) have suggested that another type of sheet containing 5- and 8-membered rings of $\mathrm{SiO}_{4}$ tetrahedra occurs in the calcium silicate okenite, but this has yet to be confirmed by a full structure determination. 


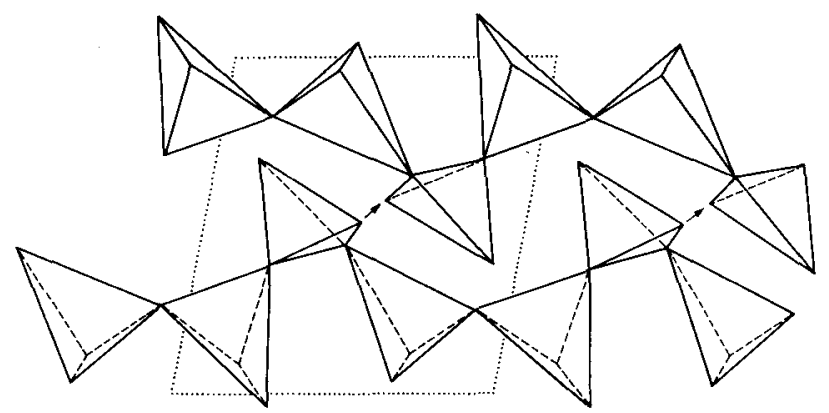

Fig.4. Distorted $\beta$-wollastonite chains. Arrows indicate how successive distorted chains link to form the dalyite $\left(\mathrm{Si}_{2} \mathrm{O}_{5}\right)$ sheet

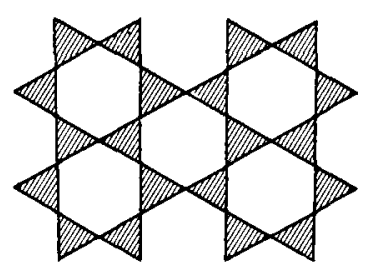

a)

(I)

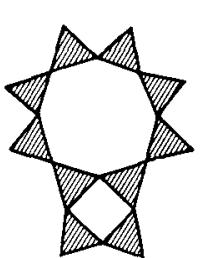

(II)

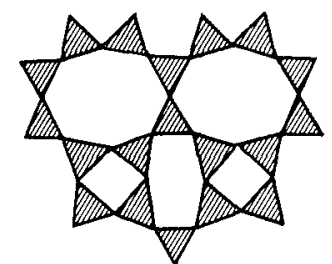

(III)

Fig. 5A. Three types of layer silicate now known. (i), (ii) and (iii) are idealized mica, apophyllite and dalyite sheets respectively

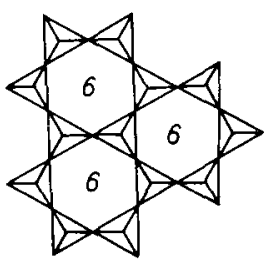

(I)

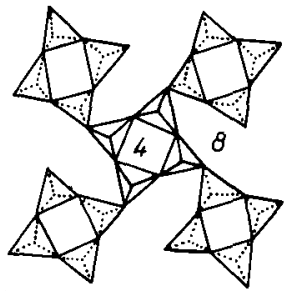

b)

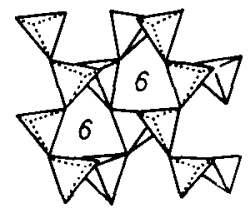

(II)

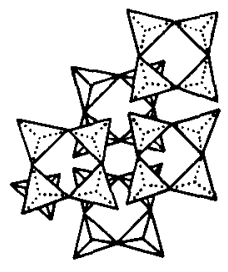

(V)

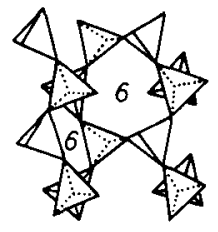

(III)

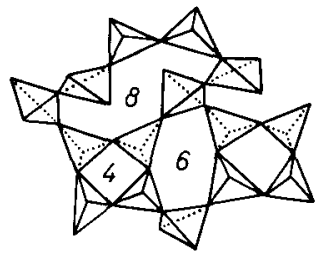

(VI)

Fig.5B. $\mathrm{SiO}_{4}$ tetrahedral network in (i) mica, (ii) $\mathrm{Li}_{2} \mathrm{Si}_{2} \mathrm{O}_{5}$, (iii) potalite, (iv) apophyllite, (v) gillespite, (vi) dalyite 
constituent chain. On this scheme dalyite would be "Dreiereinfachschichten" type since its sheet structure is made up of wollastonite chains whose repeat length is three tetrahedra.

It is interesting to compare the structure of dalyite with those of other potassium and sodium zirconium silicates. The minerals most closely related chemically to dalyite are wadeite $\left(\mathrm{K}_{2} \mathrm{ZrSi}_{3} \mathrm{O}_{9}\right)$, catapleiite $\left(\mathrm{NaZrSi}_{3} \mathrm{O}_{9} \cdot 2 \mathrm{H}_{2} \mathrm{O}\right)$, lovozerite $\left(\mathrm{Na}_{2} \mathrm{ZrSi}_{6} \mathrm{O}_{15} \cdot 3 \mathrm{H}_{2} \mathrm{O} \cdot 0.5 \mathrm{NaOH}\right)$ and elpidite $\left(\mathrm{Na}_{2} \mathrm{ZrSi}_{6} \mathrm{O}_{15} \cdot 3 \mathrm{H}_{2} \mathrm{O}\right)$. In wadeite (Henshaw, 1955) and catapleiite (BRUNovskn, 1936), the $\mathrm{Si}-\mathrm{O}$ radical is a triple $\mathrm{Si}_{3} \mathrm{O}_{9}$ ring of $\mathrm{SiO}_{4}$ tetrahedra; the rings being linked by a hexagonal array of $\mathrm{Zr}$ octahedra and $\mathrm{KO}_{9}$ polyhedra in wadeite and by a similar hexagonal array of $\mathrm{Zr}$ octahedra and $\mathrm{Na}$ decahedra in catapleiite. Elpidite has been supposed (ef. ILYUKHIN and BELOv, 1960) to contain a two-level

Table 5(i). Cation-anion bond lengths

\begin{tabular}{|c|c|c|c|c|}
\hline Cation & Type of oxygen & Bond length & $\begin{array}{c}\sigma \text { (bond length) } \\
\text { cf. Table } 4\end{array}$ & $\begin{array}{c}\text { Mean cation-anion } \\
\text { distance }\end{array}$ \\
\hline $\mathrm{Zr}$ & $\begin{array}{l}\mathrm{O}_{3} \\
\mathrm{O}_{4} \\
\mathrm{O}_{6}\end{array}$ & $\begin{array}{l}2.028 \AA \\
2.073 \\
2.090\end{array}$ & 0.012 & $2.06 \pm .03 \AA$ \\
\hline $\mathrm{K} / \mathrm{Na}$ & $\begin{array}{l}\mathrm{O}_{3} \\
\mathrm{O}_{4} \\
\mathrm{O}_{6} \\
\mathrm{O}_{7} \\
\mathrm{O}_{8} \\
\mathrm{O}_{2} \\
\mathrm{O}_{4} \\
\mathrm{O}_{5} \\
\mathrm{O}_{8} \\
\mathrm{O}_{7}\end{array}$ & $\begin{array}{c}(3.494) \\
2.825 \\
2.880 \\
3.016 \\
3.150 \\
3.117 \\
2.962 \\
3.001 \\
(3.414) \\
3.240\end{array}$ & 0.015 & $3.02 \pm .13$ \\
\hline $\mathrm{Si}_{1}$ & $\begin{array}{l}\mathrm{O}_{1} \\
\mathrm{O}_{7} \\
\mathrm{O}_{8} \\
\mathrm{O}_{6}\end{array}$ & $\begin{array}{l}1.622 \\
1.540 \\
1.644 \\
1.561\end{array}$ & 0.013 & $1.59 \pm .04$ \\
\hline $\mathrm{Si}_{2}$ & $\begin{array}{l}\mathrm{O}_{3} \\
\mathrm{O}_{7} \\
\mathrm{O}_{5} \\
\mathrm{O}_{2}\end{array}$ & $\begin{array}{l}1.664 \\
1.658 \\
1.626 \\
1.600\end{array}$ & 0.013 & $1.64 \pm .03$ \\
\hline $\mathrm{Si}_{3}$ & $\begin{array}{l}\mathrm{O}_{2} \\
\mathrm{O}_{4} \\
\mathrm{O}_{5} \\
\mathrm{O}_{8}\end{array}$ & $\begin{array}{l}1.604 \\
1.624 \\
1.672 \\
1.650\end{array}$ & 0.013 & $1.64 \pm .03$ \\
\hline
\end{tabular}


trigonal ring (doubled catapleiite ring), but its structure is not known in detail. Lovozerite contains isolated six-membered $\mathrm{Si}-\mathrm{O}$ rings linked by an approximately cubic network of $\mathrm{Zr}$ octahedra which lie at the corners of a cell $7.31 \AA \times 7.31 \AA \times 7.33 \AA$ (ILYUkHIN and BELOv, 1960). Comparison of the cell dimensions of lovozerite with dalyite led ILYUKHIN and BELOv to suppose that slight deformation of the (almost) cubic cell to make it triclinic, together with a linkage of the free corners of tetrahedra in one ring with similar corners in another would make a chain of tetrahedra corresponding to the radical $\mathrm{Si}_{6} \mathrm{O}_{15}$ and would be a possible model for dalyite. The complete structure determination, however, shows that the $\mathrm{Si}_{6} \mathrm{O}_{15}$ linkage in dalyite is not a chain but the corrugated sheet which has been described.

\section{Bond lengths}

Table 5(i) lists cation-anion bond lengths. The standard deviations of bond lengths within each polyhedron are shown in the last column of the table. All of these are so much greater than the error estimated

Table 5(ii). $O-O$ distances

\begin{tabular}{|c|c|c|c|}
\hline Atoms & Separation & $\sigma$ (bond length) & \\
\hline \multicolumn{4}{|l|}{$\mathrm{Si}_{1}$ tetrahedron } \\
\hline $\mathrm{O}_{1}-\mathrm{O}_{6}$ & $2.612 \AA$ & .020 & \multirow{6}{*}{$\begin{array}{l}\text { Mean } \\
=2.59 \pm .05 \AA\end{array}$} \\
\hline $\mathrm{O}_{1}-\mathrm{O}_{7}$ & 2.525 & & \\
\hline $\mathrm{O}_{\mathrm{L}}-\mathrm{O}_{8}$ & 2.610 & & \\
\hline $\mathrm{O}_{6}-\mathrm{O}_{7}$ & 2.558 & & \\
\hline $\mathrm{O}_{6}-\mathrm{O}_{8}$ & 2.680 & & \\
\hline $\mathrm{O}_{7}-\mathrm{O}_{8}$ & 2.577 & & \\
\hline \multicolumn{4}{|l|}{$\mathrm{Si}_{2}$ tetrahedron } \\
\hline $\mathrm{O}_{2}-\mathrm{O}_{3}$ & 2.714 & .020 & \multirow{6}{*}{$\begin{array}{l}\text { Mean } \\
=2.67 \pm .08 \AA\end{array}$} \\
\hline $\mathrm{O}_{2}-\mathrm{O}_{5}$ & 2.608 & & \\
\hline $\mathrm{O}_{2}-\mathrm{O}_{7}$ & 2.596 & & \\
\hline $\mathrm{O}_{3}-\mathrm{O}_{5}$ & 2.698 & & \\
\hline $\mathrm{O}_{3}-\mathrm{O}_{7}$ & 2.804 & & \\
\hline $\mathrm{O}_{5}-\mathrm{O}_{7}$ & 2.603 & & \\
\hline \multicolumn{4}{|l|}{$\mathrm{Si}_{3}$ tetrahedron } \\
\hline $\mathrm{O}_{2}-\mathrm{O}_{4}$ & 2.670 & .020 & \multirow{6}{*}{$\begin{array}{l}\text { Mean } \\
=2.67 \pm .03 \AA\end{array}$} \\
\hline $\mathrm{O}_{2}-\mathrm{O}_{5}$ & 2.658 & & \\
\hline $\mathrm{O}_{2}-\mathrm{O}_{8}$ & 2.637 & & \\
\hline $\mathrm{O}_{4}-\mathrm{O}_{5}$ & 2.676 & & \\
\hline $\mathrm{O}_{4}-\mathrm{O}_{8}$ & 2.728 & & \\
\hline $\mathrm{O}_{5}-\mathrm{O}_{8}$ & 2.670 & & \\
\hline
\end{tabular}


Table 5(iii). Interatomic bond angles

\begin{tabular}{|c|c|c|}
\hline Atoms & \multicolumn{2}{|c|}{ Angle } \\
\hline $\begin{array}{l}\text { Zr octahedron } \\
\qquad \begin{array}{l}\mathrm{O}_{3}-\mathrm{Zr}-\mathrm{O}_{4} \\
\mathrm{O}_{3}-\mathrm{Zr}-\mathrm{O}_{6} \\
\mathrm{O}_{4}-\mathrm{Zr}-\mathrm{O}_{6}\end{array}\end{array}$ & $\begin{array}{l}92.3^{\circ} \\
92.6 \\
92.5\end{array}$ & \\
\hline $\begin{array}{l}\mathrm{Si}_{1} \text { tetrahedron } \\
\qquad \mathrm{O}_{1}-\mathrm{Si}_{1}-\mathrm{O}_{6} \\
\mathrm{O}_{1}-\mathrm{Si}_{1}-\mathrm{O}_{7} \\
\mathrm{O}_{1}-\mathrm{Si}_{1}-\mathrm{O}_{8} \\
\mathrm{O}_{6}-\mathrm{Si}_{1}-\mathrm{O}_{7} \\
\mathrm{O}_{6}-\mathrm{Si}_{1}-\mathrm{O}_{8} \\
\mathrm{O}_{7}-\mathrm{Si}_{1}-\mathrm{O}_{8}\end{array}$ & $\begin{array}{l}110.3^{\circ} \\
106.0 \\
106.5 \\
111.1 \\
115.0 \\
108.6\end{array}$ & Mean $=109.6$ \\
\hline $\begin{array}{l}\mathrm{Si}_{2} \text { tetrahedron } \\
\qquad \begin{array}{l}\mathrm{O}_{2}-\mathrm{Si}_{2}-\mathrm{O}_{3} \\
\mathrm{O}_{2}-\mathrm{Si}_{2}-\mathrm{O}_{5} \\
\mathrm{O}_{2}-\mathrm{Si}_{2}-\mathrm{O}_{7} \\
\mathrm{O}_{3}-\mathrm{Si}_{2}-\mathrm{O}_{5} \\
\mathrm{O}_{3}-\mathrm{Si}_{2}-\mathrm{O}_{7} \\
\mathrm{O}_{5}-\mathrm{Si}_{2}-\mathrm{O}_{7}\end{array}\end{array}$ & $\begin{array}{l}112.5^{\circ} \\
107.9 \\
105.7 \\
110.2 \\
115.2 \\
104.9\end{array}$ & Mean $=109.4^{\circ}$ \\
\hline $\begin{array}{l}\mathrm{Si}_{3} \text { tetrahedron } \\
\qquad \begin{array}{l}\mathrm{O}_{2}-\mathrm{Si}_{3}-\mathrm{O}_{4} \\
\mathrm{O}_{2}-\mathrm{Si}_{3}-\mathrm{O}_{5} \\
\mathrm{O}_{2}-\mathrm{Si}_{3}-\mathrm{O}_{8} \\
\mathrm{O}_{4}-\mathrm{Si}_{3}-\mathrm{O}_{5} \\
\mathrm{O}_{4}-\mathrm{Si}_{3}-\mathrm{O}_{8} \\
\mathrm{O}_{5}-\mathrm{Si}_{3}-\mathrm{O}_{8}\end{array}\end{array}$ & $\begin{array}{l}111.6^{\circ} \\
108.4 \\
108.3 \\
108.5 \\
112.9 \\
107.0\end{array}$ & Mean $=109.5^{\circ}$ \\
\hline $\begin{array}{l}\text { Oxygen coordination angle } \\
\qquad \begin{aligned} \mathrm{Si}_{1}-\mathrm{O}_{1}-\mathrm{Si}_{1} \\
\mathrm{Si}_{1}-\mathrm{O}_{7}-\mathrm{Si}_{2} \\
\mathrm{Si}_{1}-\mathrm{O}_{8}-\mathrm{Si}_{3} \\
\mathrm{Si}_{2}-\mathrm{O}_{2}-\mathrm{Si}_{3} \\
\mathrm{Si}_{2}-\mathrm{O}_{5}-\mathrm{Si}_{3}\end{aligned}\end{array}$ & $\left.\begin{array}{l}180^{\circ} \\
145.4 \\
130.2 \\
146.4 \\
132.6\end{array}\right\}$ & Mean $=138.6^{\circ}$ \\
\hline
\end{tabular}

from $\sigma\left(x_{n}\right)$ as to suggest a real scatter of bond lengths within a polyhedron.

The average $\mathrm{Si}-\mathrm{O}$ distance is $1.62 \pm .02 \AA$, which is in good agreement with the value $1.619 \AA$ obtained from SMITH and BAILEY's curve (Smith and BaIley, 1963) for a silicate with an O:Si ratio of $5: 2$.

The average $\mathrm{Zr}-\mathrm{O}$ distance is $2.06 \pm .03 \AA$, close to the value $2.07 \AA$, found in the structure of the chemically similar wadeite (Henshaw, 1955). 
$\mathrm{K} / \mathrm{Na}-\mathrm{O}$ distances vary considerably, but the average of $3.02 \AA$ compares with the value $3.11 \AA$ in wadeite where the site is entirely occupied by $\mathrm{K}$. The very high anisotropy exhibited by the $\mathrm{K} / \mathrm{Na}$ atom is rather large to be caused solely by thermal motion, and it may be that the atom occupies two different sites about $0.25 \AA$ apart with approximately equal probability. For this reason the average $\mathrm{K} / \mathrm{Na}-\mathrm{O}$ bond lengths in Table 5 may not correspond to any real cation-anion links. Only a full three-dimensional analysis could settle the matter.

\section{Bond angles}

Table 5(iii) gives $\mathrm{O}-\mathrm{Si}-\mathrm{O}$ and $\mathrm{Si}-\mathrm{O}-\mathrm{Si}$ angles. $\mathrm{O}-\mathrm{Si}-\mathrm{O}$ angles within tetrahedra have the spread in values usually found in silicates and do not include any unusual features. $\mathrm{Si}-\mathrm{O}-\mathrm{Si}$ values, however, include one angle of $180^{\circ}$ across the oxygen $O_{1}$ at the special position $\frac{1}{2} \frac{1}{2} \frac{1}{2}$. Liebau (1961d) has reviewed $\mathrm{Si}-\mathrm{O}-\mathrm{Si}$ angles in crystalline silicates and divided them into two types, one type across oxygens near special or accidentally-simple positions having values more than $160^{\circ}$, the other type across oxygens which are not near special positions having values between $129^{\circ}$ and $166^{\circ}$ with an average angle of about $140^{\circ}$. The angle across $O_{1}$ in dalyite is of the first type, and other angles across $\mathrm{O}_{2}, \mathrm{O}_{5}, \mathrm{O}_{7}$ and $\mathrm{O}_{8}$ of the second type having an average value of $139^{\circ}$. LIEBAU $(1961 \mathrm{a}, \mathrm{b}, \mathrm{c})$ investigated the structures of $\mathrm{Li}_{2} \mathrm{Si}_{2} \mathrm{O}_{5}, \alpha \mathrm{Na}_{2} \mathrm{Si}_{2} \mathrm{O}_{5}$ and petalite which have angles of the first type, and found that although there was marked pseudo-symmetry in each case, the oxygen involved in the bond was in fact slightly displaced from the special position it would have occupied if full symmetry operated. The result of this was to reduce the $\mathrm{Si}-\mathrm{O}-\mathrm{Si}$ angle from $180^{\circ}$ to a value close to $160^{\circ}$. Liebau (1961d) went on from this to suggest in a later paper that $180^{\circ} \mathrm{Si}-\mathrm{O}-\mathrm{Si}$ bonds would not exist in silicates, and to predict that structures such as thortveitite, zunyite, coesite etc. which had previously been found to have $180^{\circ} \mathrm{Si}-\mathrm{O}-\mathrm{Si}$ angles would be found on closer inspection to be pseudo-symmetric, the oxygen being displaced from the pseudo-special position to reduce the $\mathrm{Si}-\mathrm{O}-\mathrm{Si}$ angle to about $160^{\circ}$.

Cruickshank, Lynton and Barclay (1962) however, have recently refined thortveitite by least-squares methods with full threedimensional data and have concluded that it retains the full symmetry (space group $C 2 / m$ ) and the $180^{\circ} \mathrm{Si}-\mathrm{O}-\mathrm{Si}$ angle of the original structure (ZaChariasen, 1930). Cruickshank et al. point out that 
the zunyite and coesite determinations are of fairly high quality, and that in these cases too, the $180^{\circ} \mathrm{Si}-\mathrm{O}-\mathrm{Si}$ angles could only be discounted after very careful refinement.

Figure 6 shows (100), (010) and (001) electron-density projections of the $\mathrm{O}_{1}$ atom in dalyite. The anisotropy previously referred to (Section 7, Table 4) can be clearly seen. In view of LiEBaU's suggestion (LiEBAU, 1961d), it was thought that the anisotropy might be the result of a wrongly-imposed centre of symmetry, the oxygen actually being displaced from the special position $\frac{1}{2} \frac{1}{2} \frac{1}{2}$. The anisotropy of the $\mathrm{K} / \mathrm{Na}$ atom could also be due to the same thing. Accordingly $\mathrm{O}_{1}$ was

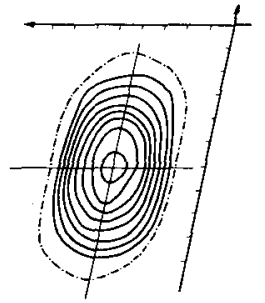

(I)

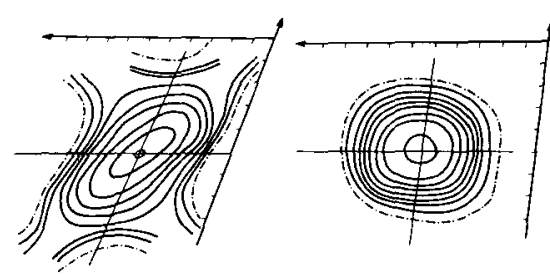

(II)

(III)

Fig. 6. Electron-density projections of oxygen atom $\mathrm{O}_{1}$ along $x, y$ and $z$ axes respectively. Axial directions divided into 64ths of the cell edges are shown

moved off the special position and refinement was continued on the assumption that the structure was non-centrosymmetric. At the limit of refinement, the $R$ factors on the three projections had been reduced by $0.8 \%, 0.6 \%$ and $0.9 \% ; \mathrm{O}_{1}$ had moved about $0.1 \AA$ from its former site, and the $\mathrm{Si}_{1}-\mathrm{O}_{1}-\mathrm{Si}_{1}$ angle had dropped to $173^{\circ}$. The improvement in $R$ factors and in the flatness of the difference maps was so marginal that it was not thought to be significant. Removing the centre of symmetry in any case increased the number of variable parameters from 47 to 62 , so that some improvement in $R$ values and difference maps would have been expected. Contours round the $O_{1}$ atom on electron-density maps were, however, more nearly circular than those in Fig. 6:- a point in favour of the lower symmetry structure. What does seem clear is that there is definite departure from a strictly straight $\mathrm{Si}_{1}-\mathrm{O}_{1}-\mathrm{Si}_{1}$ linkage. If the structure is centro-symmetric this takes the form of anisotropic thermal motion of the oxygen; if not, an actual displacement of the oxygen from the special site. Careful refinement with full three-dimensional data would be needed to 
discover the correct answer. In lieu of this, the conventional assumption of higher symmetry ( $\overline{\overline{1}}$ space group) has been made when listing the coordinates, bond lengths and bond angles.

\section{Acknowledgements}

I am grateful to Dr. P. GAY who provided me with the sample of dalyite and arranged for the collection of some of the $\mathrm{x}$-ray data, and to Mr. K. O. Rrckson who took some of the x-ray photographs.

\section{References}

B. K. BRunovskiI (1936), The structure of katapleiite. Acta Physicochem. USSR 5, 863-892.

W. Cochran (1951), Some properties of the $\left(F_{0}-F_{0}\right)$-synthesis. Acta Crystallogr. 4, 408-411.

D. W. J. Cruiokshank, H. Lynton and G. A. Barclay (1962), A reinvestigation of the crystal structure of thortveitite $\mathrm{Sc}_{2} \mathrm{Si}_{2} \mathrm{O}_{7}$. Acta Crystallogr. 15, $491-498$.

C. H. Dauben and D. H. Templeton (1955), A table of dispersion corrections for x-ray scattering of atoms. Acta Crystallogr. 8, 841-842.

R. M. Douglass (1958), The crystal structure of sanbornite, $\mathrm{BaSi}_{2} \mathrm{O}_{5}$. Amer. Min. 43, 517-536.

M. C. M. Farquhar and H. Lipson (1946), The accurate determination of cell dimensions from single-crystal x-ray photographs. Proc. Physic. Soc. [London] $58,200-206$.

J. B. Forsyth and M. WeLls (1959), On an analytic approximation to the atomic scattering factor. Acta Crystallogr. 12, 412-415.

D. E. Henshaw (1955), The structure of wadeite. Mineral. Mag. 30, 585-595.

E. R. Howells, D. C. Philltrs and D. Rogers (1950), The probability distribution of x-ray intensities. II. Experimental investigation and the x-ray detection of centres of symmetry. Acta Crystallogr. 3, 210-214.

V. V. Ilyukhin and N. V. Belov (1960), Derivation of the structure of lovozerite from sections of the three-dimensional Patterson function. Crystallography 5, 186-198.

F. LiebaU (1961a), Untersuchungen an Schichtsilikaten des Formeltyps $A_{m}\left(\mathrm{Si}_{2} \mathrm{O}_{5}\right) n$. I. Die Kristallstruktur der Zimmertemperaturform des $\mathrm{Li}_{2} \mathrm{Si}_{2} \mathrm{O}_{5}$. Acta Crystallogr. 14, 389-395.

- (1961b), II. Über die Kristallstruktur des $\alpha-\mathrm{Na}_{2} \mathrm{Si}_{2} \mathrm{O}_{5}$. Acta Crystallogr. 14, 395-398.

- (1961c), III. Zur Kristallstruktur von Petalit, LiAlSi ${ }_{4} \mathrm{O}_{10}$. Acta Crystallogr. 14, 399-406.

- (1961 d), Untersuchungen über die Größe des Si-O-Si-Valenzwinkels. Acta Crystallogr. 14, 1103-1109.

- (1962), Die Systematik der Silikate. Naturwissenschaften 49, 481-491.

Ch. Mamedov and N. V. Belov (1958), Crystal structure of mica-like, hydrous calcium silicates: okenite, nekoite, truscottite and gyrolite. Dokl. Akad. Nauk SSSR 121, 713-716. 
A. Pabst (1943), Crystal structure of gillespite, $\mathrm{BaFeSi}_{4} \mathrm{O}_{10}$. Amer. Min. 28, $372-390$.

G. N. Ramachandran and R. Srinivasan (1959), A new statistical test for distinguishing between centrosymmetric and non-centrosymmetric structures. Acta Crystallogr. 12, 410-411.

J. M. Robertson (1943), Technique of intensity measurements in x-ray crystal analysis by photographic methods. J. Sci. Instrum. 20, 175-179.

J. V. Smith and S. W. BaIley (1963), Second review of Al--O and Si-O tetrahedral distances. Acta Crystallogr, 16, 801--811.

W. H. TAylor and St. NÁRAY-SzaBó (1931), The structure of apophyllite. Z. Kristallogr. 77, 146-158.

R. Van Tassel (1952), Dalyite, a new potassium zirconium silicate, from Ascension Island, Atlantic. Mineral. Mag. 29, 850-857.

O. Weisz, W. Cochran and W. F. Cole (1948), The accurate determination of cell dimensions from single-crystal x-ray photographs. Acta Crystallogr. 1, $83-88$.

W. H. ZACharIasen (1930), The structure of thortveitite, $\mathrm{Se}_{2} \mathrm{Si}_{2} \mathrm{O}_{7}$. Z. Kristallogr. 73, 1-6. 